\title{
Sedentary behavior based on screen time: prevalence and associated sociodemographic factors in adolescents
}

\author{
Comportamento sedentário baseado em tempo de tela: \\ prevalência e fatores sociodemográficos associados em adolescentes
}

Gabriel Renaldo de Sousa ${ }^{1}$

Diego Augusto Santos Silva ${ }^{1}$

${ }^{1}$ Centro de Ciências da Saúde, Universidade Federal de Santa Catarina. Campus Reitor João David Ferreira Lima s/n, Trindade. 88040-900 Florianópolis SC Brasil. gabrielrdesousa@gmail.com
Abstract The aim of this study to estimate the prevalence of sedentary behavior based on screen time ( $\geq 2$-hour day) and to identify the association with sociodemographic factors among adolescents in a city in southern Brazil. This is an epidemiological survey of school-based cross-sectional study with students aged 14-19 years in the city of São José/SC - Brazil. Self-administered questionnaire was used, containing information sociodemographic, level of physical activity and about screen time. Descriptive statistics were performed, and odds ratios were estimated using binary logistic regression and 95\% confidence level. The prevalence of excess screen time was $86.37 \%$ followed by computer use (55.24\%), TV use (51.56\%) and Videogame use (15.35\%). Boys had higher prevalence of excessive video game use. Those of skin color different from white and mothers who studied less than eight years were more likely to watch too much TV, and those of low economic level were more likely of having excessive screen time. Girls of skin color different from white were more likely to watch too much TV, and those aged 14-16 years were more likely to have videogame use time and total time screen above recommended.

Key words Epidemiology, Motor activity, Sedentary lifestyle, Socioeconomic factors, Cross-sectional study
Resumo Oobjetivo deste estudo foi estimar a prevalência de comportamentos sedentários baseado em tempo de tela ( $\geq 2$ horas por dia) e identificar a associação com fatores sociodemográficos $\mathrm{em}$ adolescentes, de uma cidade do Sul do Brasil. Esta é uma pesquisa epidemiológica de base escolar com delineamento transversal, em estudantes de 14 a 19 anos na cidade de São José/SC, Brasil. Foi utilizado questionário autoaplicado, com informações sociodemográficas, atividade física e tempo de uso de tela. Foi realizada estatística descriti$v a, e$ as razões de chances estimadas por regressão logística binária. A prevalência de uso excessivo de tela foi de $86,37 \%$ seguido de uso de computador (PC) (55,24\%), televisão (TV) (51,56\%) e videogame (VG) (15,35\%). Os meninos tiveram maior prevalência de uso excessivo de VG. Aqueles de cor de pele diferente de branca e que mães estudaram menos de oito anos tiveram mais chances de assistirem TV em excesso, e aqueles, de baixo nível econômico tiveram mais chances de terem tempo total de tela excessivo. Meninas de cor de pele diferente de branca tiveram mais de assistirem TV em excesso, e aquelas com 14 a 16 anos tiveram mais chances de estarem com tempo de uso de VG e tempo total de tela acima do recomendado.

Palavras-chave Epidemiologia, Atividade motora, Estilo de vida sedentário, Fatores socioeconômicos, Estudo transversal 


\section{Introduction}

Sedentary behavior based on screen time is associated with health problems such as increased risk of obesity, hypertension, hypertriglyceridemia, low bone mineral levels, psychosocial problems and low self-esteem in adolescents ${ }^{1,2}$. Longitudinal studies have shown that screen exposure levels increased rapidly in all regions of the world, becoming a public health problem ${ }^{3,4}$.

Systematic review carried out by Thorp et al. ${ }^{5}$ with 48 longitudinal studies published between 1996 and January 2011 in Web of Science, MEDLINE, PubMed and PsycINFO databases indicated consistent relationship between high time of sedentary behavior during adolescence and higher risk of obesity and mortality during adulthood. In addition, the authors showed directly proportional association of sedentary behavior with metabolic risk biomarkers (leptin and cholesterol).

Like other health outcomes, sedentary behavior suffers direct influence from sociodemographic factors as indicated in the study carried out by Rey-López et al. ${ }^{6}$ in Spain, in which lower economic class adolescents and those whose mothers had lower schooling dedicated more time watching television (TV). Pate et al. ${ }^{7}$ reviewed articles that sought factors associated with sedentary behavior between 1990 and 2010 and found that non-white and low economic level young people dedicated longer time on screenbased sedentary behavior.

Two studies carried out in northeastern Bra$\mathrm{zil}^{8,9}$ analyzed the time spent in front of the TV and indicated that girls spend more time watching TV; however, they found no relationship between parental schooling and skin color with sedentary behavior. Another survey conducted in southern Brazil ${ }^{10}$ analyzed computer (PC) and videogame time (VG) and found no correlation with gender and age. However, when the researchers analyzed the same data including the total hours of TV, PC and VG, age was inversely associated with total screen time ${ }^{11}$.

Adolescents who are sedentary are likely to gain weight, have high blood pressure and more depressive problems compared with their peers who spend less time sitting in front of the TV, PC and VG. Sociodemographic factors are associated with the time that adolescents spend sitting in front of these electronic ${ }^{7,11-13}$. For example, in a study of European adolescents, the time sitting in front of the TV was higher in adolescents with worse socioeconomic indicators. However, the time sitting in front of PC and VG was higher in those of better socioeconomic indicators ${ }^{6,14}$.

In Brazil, most studies only investigate one type of sedentary behavior based on screen time. Some studies have investigated only time that adolescents would sit in front of the TV, and others have investigated the time that young people passed in front of the $\mathrm{PC}$ and $\mathrm{VG}^{8-10,13}$. This study aims to verify in the same sample which factors are associated with different types of sedentary behaviors based on screen time. This study gives an overview of the problem and may suggest strategies in public health to improve quality of life and health of adolescentes ${ }^{1}$.

The aim of this study was to estimate the prevalence of different sedentary behaviors based on screen time (TV, PC, VG and total screen time) and identify the association with sociodemographic factors (gender, age, skin color, maternal education and economic status) in adolescents living in a city in southern Brazil.

\section{Method}

This study was part of the Brazilian Guide for Evaluation of Physical Fitness Related to Health and Life Habits, funded by the National Council for Scientific and Technological Development (CNPq). The target population of this research was adolescents aged 14-19 years enrolled in high schools of São José, SC, Brazil. The study was approved by the Ethics Committee on Human Research of Fedeal niversity of Santa Catarina, Brazil.

The city of São José is located in the Brazilian state of Santa Catarina, bordering the state capital, Florianopolis. The Human Development Index (IDH) of the city is 0.809 and the per capita income is R $\$ 1.157,43$ and the GINI index is 0.44 . The percentage of young people aged 15-17 years with complete primary education is $70.94 \%$ and life expectancy at birth is 77.81 years ${ }^{15}$.

According to information from the State Department of Education of Santa Catarina, the city of São José had in the second half of 20145,182 students enrolled in 11 eligible high schools and 170 classes distributed in the high school grades. Of that number of students, $74.8 \%$ were of the day shift (morning, afternoon or full).

The sampling process was determined in two stages: 1) public high schools; 2) class clusters, considering school shift and school grade. Schools that met only people with some type of disability and classes for the education of Adults 
were excluded. In the first stage, school density was adopted as a stratification criterion (small, with less than 200 students; intermediate, with 200-499 students; and large, with 500 students or more); thus, schools that prevailed according to their size were proportionally selected. In the second stage, school shift and school grade were considered.

Confidence level of 1.96 (95\% confidence interval), tolerable error of five percentage points, prevalence of 50\% (unknown outcome), and design effect of 1.5 were adopted ${ }^{16}$. The sample was added of $20 \%$ to minimize possible losses and refusals and another $20 \%$ for the control of potential confounders in association studies ${ }^{17}$.

Due to cluster sampling, all students of classes were invited to participate. Adolescents 1419 years of age, both sexes, who returned the consent form signed by parents $(<18$ years old) or themselves ( $\geq 18$ years) were eligible for the survey. Adolescents who refused to participate in the study were considered as a refusal. Those students who did not answer any questions about sedentary behavior were excluded from the final sample, resulting in 1,085 adolescents.

\section{Study variables}

The dependent variables in this study were the different sedentary behaviors based on screen time (TV, PC, VG and total screen time). Study subjects were asked about the time of TV, PC and VG use during one weekday and one weekend day. Weighted average time in the week was performed (time on weekdays times five plus time at the weekend times two. This result was divided by seven). The result was described in hours per day. For the total screen time, the sum of TV, PC and VG use during one week was considered. Similar measures were used in international studies ${ }^{12}$, with good reliability and reproducibility among adolescents (intraclass correlation coefficient - ICC $=0.76$; 95\% CI: 0.70-0.81; kappa $=0.52)^{18}$. Adolescents who spent two hours or more sitting in front of the TV, PC or VG were considered as a risk group $^{2,19}$. To add the time that adolescents spent in front of the TV, PC and VG was obtained total screen time. Adolescents who spent two hours or more this sum were considered as a risk group ${ }^{2,19}$.

The independent variables were gender (boys and girls), age (14-16 years and 17-19 years), self-reported skin color according to the Brazilian Institute of Geography and Statistics ${ }^{20}$, being dichotomized into white skin color and others (black/brown/yellow/indigenous).
Socioeconomic level was collected through instrument adopted by the Brazilian Association of Research Companies - Criterion for Economic Classification Brazil ${ }^{21}$, being dichotomized into high (A1, A2, B1 and B2) and low economic level (C1, C2, D and E). Maternal schooling was collected in years of school, being dichotomized into up to eight years of study and eight or more years of study. This variable was used to be socioeconomic indicator, with predictive power for health and well being of adolescents ${ }^{22}$. In addition, the high maternal education is associated with better living conditions and a healthier lifestyle $e^{6,8-11,13}$.

The level of physical activity was investigated through the question used in the research Youth Risk Behavior Surveillance System (YRBSS):"During the last 7 days, how many days were you physically active for at least 60 minutes a day"? This question was translated and validated for Brazilian adolescentes $(\mathrm{kappa}=0.69)^{23}$. The answer was dichotomized into according to recommendations, those who reached the recommended level were classified as "active" (5/6/7 days) and not according to recommendations they were classified as "insufficiently active" ( $<5$ days $)^{24}$.

\section{Statistical treatment}

Data were entered in duplicate in the Epidata software version 3.1 (Epidata Association, Odense, Denmark) in order to remove any kind of error during typing. Then, automatic checks for consistency and amplitude within the program itself were performed. The variables were analyzed using the chi-square test, $\mathrm{T}$ test for independent samples or the Mann-Whitney test. The time of different sedentary behaviors was significantly different between genders, so it was decided to perform a stratified analysis of associated factors.

Odds ratios were described for each behavior using binary logistic regression models. All independent variables were included in the adjusted model. Stata 11.0 statistical package was used (Stata Corp, College Station, Texas, USA) and the "SVY" command was used throughout the analysis due to the complex sample design and sample weight.

\section{Results}

This study included 1,085 adolescents who answered questions about sedentary behavior and sociodemographic factors. Of these, 489 
(45.05\%) were boys and 596 (54.95\%) were girls (Table 1). The average total screen time was 6.55 $( \pm 4.98)$, followed by PC use time $3.14( \pm 3.18) \mathrm{h} /$ day, TV $2.60( \pm 2.35) \mathrm{h} /$ day and VG $0,82( \pm 1.70)$ $\mathrm{h} /$ day. Among boys the average time to full use screen was $(7.16 \pm 5.04 \mathrm{~h} /$ day $)$, followed by PC usage $(3.47 \pm 3.08 \mathrm{~h} /$ day $)$, TV $2.39( \pm 2.25) \mathrm{h} /$ day and game $(1.30 \pm 2.01 \mathrm{~h} /$ day $)$. For the girls spent an average of $6.05( \pm 4.88) \mathrm{h} /$ day in front of the screen, 2.86( \pm 3.23$) \mathrm{h} /$ day using PC, 2.78( \pm 2.43$)$ $\mathrm{h} /$ day watching television and $0.41( \pm 125) \mathrm{h} /$ day playing video games. The boys spend more time sitting in front of the PC $(\mathrm{p}<0.01), \mathrm{VG}(\mathrm{p}<$ $0.01)$ and total screen time $(\mathrm{p}<0.01)$ compared with girls. The girls spent more time sitting in front of the TV $(\mathrm{p}<0.01)$ compared with boys (data not shown in tables and/or graphics).
More than $85 \%$ of the sample was exposed time exceeding two hours of total screen time. When considering the type of sedentary behavior based on screen time, the highest prevalence was students sitting in front of PC (55.24\%), followed by the TV (51.56\%), and VG (15.35\%). Boys had higher prevalence of VG use compared the girls and the girls showed the highest prevalence of insufficiently active. Most adolescents were in the age group of 14-16 years (59.56\%) and had white skin color $(62.88 \%)$. With regard to economic variables, almost $70 \%$ of the sample was of high economic level; however, most mothers had schooling less than eight years (56.14\%) (Table 1).

For boys, the prevalence of TV time above the recommended was higher in those whose mothers

Table 1. Absolute and relative frequency and 95\% confidence interval of the sample variables. São José, SC, Brazil $-2014$.

\begin{tabular}{|c|c|c|c|c|c|c|}
\hline \multirow{2}{*}{ Variable } & \multicolumn{2}{|r|}{ Total sample } & \multicolumn{2}{|r|}{ Boys } & \multicolumn{2}{|r|}{ Girls } \\
\hline & n & $\%(95 \% \mathrm{CI})$ & $\mathbf{n}$ & $\%(95 \% \mathrm{CI})$ & n & $\%(95 \% \mathrm{CI})$ \\
\hline Total & 1.085 & 100 & 489 & $45.05(35.57-54.91)$ & 596 & $54.95(45.08-64.42)$ \\
\hline TV & & & \multicolumn{4}{|c|}{$\mathrm{p}=0.10$} \\
\hline$<2$ hours & 528 & $48.43(44.86-52.03)$ & 259 & $52.81(48.59-56.98)$ & 269 & $44.85(35.92-54.13)$ \\
\hline$\geq 2$ hours & 557 & $51.56(47.96-55.13)$ & 230 & $47.18(43.01-51.40)$ & 327 & $55.14(45.86-64.07)$ \\
\hline PC & & & \multicolumn{4}{|c|}{$\mathrm{p}=0.13$} \\
\hline$<2$ hours & 484 & $44.75(39.73-49.88)$ & 183 & $37.78(28.89-47.58)$ & 301 & $50.46(37.57-6.29)$ \\
\hline$\geq 2$ hours & 601 & $55.24(50.11-60.26)$ & 306 & $62.21(52.41-71.11)$ & 295 & $49.53(36.70-62.42)$ \\
\hline VG & & & \multicolumn{4}{|c|}{$\mathrm{p}<0.01$} \\
\hline$<2$ hours & 919 & $84.64(74.73-91.12)$ & 367 & $75.02(63.10-84.07)$ & 552 & 92.53 (88.79-95.09) \\
\hline$\geq 2$ hours & 166 & $15.35(8.87-25.26)$ & 122 & $24.29(15.92-36.89)$ & 44 & $7.46(4.90-11.20)$ \\
\hline Screen time & & & \multicolumn{4}{|c|}{$\mathrm{p}=0.11$} \\
\hline$<2$ hours & 149 & $13.62(8.56-20.97)$ & 45 & $9.11(6.28-13.04)$ & 104 & $17.32(8.26-32.76)$ \\
\hline$\geq 2$ hours & 936 & 86.37 (79.02-91.43) & 444 & 90.88 (86.95-93.71) & 492 & $82.67(67.23-91.73)$ \\
\hline Age & & & \multicolumn{4}{|c|}{$\mathrm{p}=0.05$} \\
\hline $14-16$ years & 648 & $59.56(55.23-63.69)$ & 277 & $56.60(49.60-63.35)$ & 371 & $61.98(58.02-65.79)$ \\
\hline $17-19$ years & 437 & $40.43(36.30-44.70)$ & 212 & $43.39(36.64-50.39)$ & 225 & $38.01(34.20-41.97)$ \\
\hline Skin color & & & \multicolumn{4}{|c|}{$\mathrm{p}=0.58$} \\
\hline White & 676 & $62.88(57.25-68.19)$ & 306 & $63.22(57.63-68.65)$ & 370 & $62.53(56.00-68.64)$ \\
\hline Others $^{1}$ & 400 & $37.11(31.80-42.74)$ & 176 & $36.67(31.34-42.36)$ & 224 & $37.46(31.35-43.99)$ \\
\hline Economic level & & & \multicolumn{4}{|c|}{$\mathrm{p}=0.12$} \\
\hline High & 639 & $69.59(63.42-75.13)$ & 297 & $73.44(66.99-79.03)$ & 342 & $66.54(55.37-76.11)$ \\
\hline Low & 283 & $30.40(24.86-36.57)$ & 110 & $26.55(20.96-33.00)$ & 173 & $33.45(23.8-44.62)$ \\
\hline Maternal schooling & & & \multicolumn{4}{|c|}{$\mathrm{p}=0.24$} \\
\hline$<8$ years & 607 & $56.14(42.59-68.83)$ & 267 & $55.10(43.47-66.19)$ & 340 & $56.99(41.38-71.32)$ \\
\hline$\geq 8$ years & 470 & $43.85(31.16-57.40)$ & 217 & $44.89(33.80-56.52)$ & 253 & $43.00(28.67-58.61)$ \\
\hline Physcial Activity & & & & \multicolumn{3}{|c|}{$p=0,02$} \\
\hline Active & 244 & $22.91(19.17-27.14)$ & 134 & $27.99(19.92-37.78)$ & 110 & $18.77(17.16-20.50)$ \\
\hline Insufficiently active & 819 & $77.08(72.85-80.82)$ & 344 & $72.0(62.21-80.07)$ & 475 & $81.22(79.49-82.83)$ \\
\hline
\end{tabular}


studied eight years or less (52.17\%; CI95\%:46.00$58.26)$ and in those of skin color different from white (52.02\%; CI:45.23-58.74). Boys of lower economic level had higher prevalence of excess total screen time (95.58\%; CI\%:92.22-97.53), and those insufficiently active showed the highest prevalence of use of pc (65.69\%; CI95\%:54.7575.19). For girls, there was a higher prevalence of sedentary behavior in relation to the excessive use of TV use among those of skin color different from white (61.24\%; CI95\%:51.93-69.79). Girls aged 14-16 years had higher prevalence of VG use (8.71\%; CI95\%:6.01-12.46) and total screen time (85.53\%; CI95\%:67.17-94.47) (Table 2).
In the crude and adjusted analysis, boys whose mothers studied less than eight years and those of skin color different from white were more likely to exceed the recommended TV time, and those insufficiently active were more odds to use PC above recommended. Boys of low economic level were more likely to have sedentary behavior when the total screen time was analyzed (Table 3).

In the crude and adjusted analysis, girls of skin color different from white were more likely to exceed the recommended TV time. Girls aged 14-16 years were more likely to exceed VG use time. Moreover, girls aged $14-16$ years were more

Table 2. Relative frequency and confidencial interval of sedentary behavior based on screen time among adolescents. São José, SC, Brazil - 2014.

\begin{tabular}{|c|c|c|c|c|}
\hline & $\begin{array}{c}\text { TV } \\
\%(95 \% \mathrm{CI}) \\
\end{array}$ & $\begin{array}{c}\text { PC } \\
\%(95 \% \mathrm{CI})\end{array}$ & $\begin{array}{c}\text { VG } \\
\%(95 \% \mathrm{CI})\end{array}$ & $\begin{array}{c}\text { SCREEN } \\
\%(95 \% \mathrm{CI})\end{array}$ \\
\hline \multicolumn{5}{|l|}{ Boys } \\
\hline Age & $p=0.97$ & $p=0.81$ & $p=0.18$ & $p=0.96$ \\
\hline $14-16$ years & $47.12(35.80-58.73)$ & $62.47(56.48-68.11)$ & $26.51(18.16-36.97)$ & $90.99(84.53-94.91)$ \\
\hline $17-19$ years & $47.29(40.84-53.83)$ & $61.87(46.38-75.27)$ & $22.96(12.81-37.68)$ & $90.76(64.78-98.13)$ \\
\hline Skin color & $p=0.03$ & $p=0.96$ & $p=0.34$ & $p=0.81$ \\
\hline White & $44.51(43.56-45.46)$ & $62.17(51.16-72.05)$ & $23.37(11.44-41.87)$ & $90.47(89.29-91.53)$ \\
\hline Others* & $52.02(45.23-58.74)$ & $62.05(49.77-72.96)$ & $27.68(22.17-33.96)$ & 91.27 (71.70-97.73) \\
\hline Maternal schooling & $p=0.01$ & $p=0.43$ & $p=0.12$ & $p=0.43$ \\
\hline$<8$ years & $52.17(46.00-58.26)$ & $60.65(55.50-65.58)$ & $22.77(17.20-29.51)$ & $90.08(84.01-94.01)$ \\
\hline$\geq 8$ years & $40.32(37.45-43.26)$ & $64.18(46.42-78.75)$ & $28.26(14.77-47.23)$ & $92.14(84.56-96.17)$ \\
\hline Economic level & $p=0.36$ & $p=0.80$ & $p=0.25$ & $p<0.01$ \\
\hline High & $45.88(43.01-48.78)$ & $63.58(62.91-64.25)$ & $24.32(17.86-32.26)$ & $90.75(86.54-93.73)$ \\
\hline Low & $49.16(34.75-63.70)$ & $64.89(43.37-81.69)$ & $26.83(18.34-32.97)$ & $95.58(92.22-97.53)$ \\
\hline Physcial Activity & $p=0.20$ & $p=0.01$ & $p=0.06$ & $p=0.05$ \\
\hline Active & $41.73(30.73-53.62)$ & $54.68(43.99-64.96)$ & $20.49(14.94-27.43)$ & $87.19(79.90-92.05)$ \\
\hline Insufficiently active & $49.98(42.44-57.52)$ & $65.69(54.75-75.19)$ & $27.73(17.28-40.14)$ & $93.23(90.04-95.46)$ \\
\hline \multicolumn{5}{|l|}{ Girls } \\
\hline Age & $p=0.18$ & $p=0.12$ & $p<0.01$ & $p=0.04$ \\
\hline $14-16$ years & $57.38(52.73-61.89)$ & $51.57(39.78-61.18)$ & $8.71(6.01-12.46)$ & $85.53(67.17-94.47)$ \\
\hline $17-19$ years & $51.51(34.91-67.78)$ & $46.23(30.89-62.31)$ & $5.44(3.17-9.19)$ & $78.2(66.12-86.59)$ \\
\hline Skin color & $p=0.01$ & $p=0.42$ & $p=0.05$ & $p=0.36$ \\
\hline White & $51.29(40.54-61.92)$ & $51.08(44.38-57.75)$ & $6.37(3.38-11.66)$ & $84.29(77.92-89.09)$ \\
\hline Others* & $61.24(51.93-69.79)$ & $47.03(25.16-70.11)$ & $9.37(7.16-12.15)$ & $79.84(48.00-94.44)$ \\
\hline Maternal schooling & $p=0.34$ & $p=0.17$ & $p=0.67$ & $p=0.12$ \\
\hline$<8$ years & $56.23(44.07-67.68)$ & $46.38(39.15-53.76)$ & $7.08(6.31-7.94)$ & $81.94(64.40-91.92)$ \\
\hline$\geq 8$ years & $53.17(45.88-60.32)$ & $53.91(31.79-74.59)$ & $8.07(2.75-21.39)$ & $83.44(69.97-91.60)$ \\
\hline Economic level & $p=0.78$ & $p=0.18$ & $p=0.84$ & $p=0.75$ \\
\hline High & $54.14(40.97-66.76)$ & $56.66(34.83-66.36)$ & $7.50(4.27-12.86)$ & $82.26(72.12-89.26)$ \\
\hline Low & $53.33(42.28-64.06)$ & $49.16(36.44-61.98)$ & $7.93(4.59-13.38)$ & $81.01(51.83-94.42)$ \\
\hline Physcial Activity & $p=0.65$ & $p=0.08$ & $p=0.82$ & $p=0.45$ \\
\hline Active & $53.51(35.55-72.41)$ & $48.26(20.32-77.33)$ & $8.46(0.83-50.49)$ & $79.90(46.51-94.79)$ \\
\hline Insufficiently active & $55.27(48.92-61.46)$ & $49.82(40.87-58.79)$ & $7.40(6.90-7.93)$ & $82.94(71.83-90.27)$ \\
\hline
\end{tabular}


Table 3. Odds Ratio and 95\% confidence interval between sedentary behaviors based on screen time and independent variables in boys. São José, SC, Brazil - 2014.

\begin{tabular}{|c|c|c|c|c|c|c|}
\hline \multirow{2}{*}{ Variable } & \multicolumn{3}{|c|}{ Crude } & \multicolumn{3}{|c|}{ Adjusted } \\
\hline & OR & 95\%CI & $\mathbf{p}$ & OR & $95 \% \mathrm{CI}$ & $\mathbf{P}$ \\
\hline \multicolumn{7}{|l|}{ Television } \\
\hline \multicolumn{7}{|l|}{ Age } \\
\hline $14-16$ years & 1 & & & 1 & & \\
\hline $17-19$ years & 1.00 & $0.49-2.05$ & 0.97 & 1.10 & $0.53-2.27$ & 0.60 \\
\hline \multicolumn{7}{|l|}{ Skin color } \\
\hline White & 1 & & & 1 & & \\
\hline Others ${ }^{\star}$ & 1.35 & $1.08-1.71$ & 0.03 & 1.58 & $1.31-1.89$ & $<0.01$ \\
\hline \multicolumn{7}{|l|}{ Maternal schooling } \\
\hline$<8$ years & 1 & & & 1 & & \\
\hline$\geq 8$ years & 0.61 & $0.49-0.78$ & 0.01 & 0.60 & $0.47-0.76$ & 0.01 \\
\hline \multicolumn{7}{|l|}{ Economic level } \\
\hline High & 1 & & & 1 & & \\
\hline Low & 1.14 & $0.69-1.85$ & 0.36 & 1.03 & $0.36-2.94$ & 0.90 \\
\hline \multicolumn{7}{|l|}{ Physcial Activity } \\
\hline Active & 1 & & & 1 & & \\
\hline Insufficiently active & 1.39 & $0.64-3.00$ & 0.20 & 1.40 & $0.62-3.13$ & 0.21 \\
\hline \multicolumn{7}{|l|}{ Computer } \\
\hline \multicolumn{7}{|l|}{ Age } \\
\hline $14-16$ years & 1 & & & 1 & & \\
\hline $17-19$ years & 0.97 & $0.63-1.49$ & 0.81 & 0.87 & $0.75-1.00$ & 0.05 \\
\hline \multicolumn{7}{|l|}{ Skin color } \\
\hline White & 1 & & & 1 & & \\
\hline Others* & 0.94 & $0.66-1.49$ & 0.96 & 0.95 & $0.80-1.13$ & 0.36 \\
\hline \multicolumn{7}{|l|}{ Maternal schooling } \\
\hline$<8$ years & 1 & & & 1 & & \\
\hline$\geq 8$ years & 1.16 & $0.59-2.27$ & 0.43 & 1.22 & $0.43-3.46$ & 0.49 \\
\hline \multicolumn{7}{|l|}{ Economic level } \\
\hline High & 1 & & & 1 & & \\
\hline Low & 1.05 & $0.44-2.52$ & 0.80 & 1.09 & $0.39-3.01$ & 0.73 \\
\hline \multicolumn{7}{|l|}{ Physcial Activity } \\
\hline Active & 1 & & & 1 & & \\
\hline Insufficiently active & 1.58 & $1.36-1.83$ & 0.01 & 1.60 & $0.91-2.80$ & 0.06 \\
\hline
\end{tabular}

likely to exceed the recommended time for total screen time (Table 4).

\section{Discussion}

The following are among the main results found: sedentary behavior based on screen time (TV, PC, VG and total screen time) was different between sexes; boys had higher prevalence of VG use. Boys with skin color different from white and those whose mothers studied less than eight years were respectively $58 \%$ and $40 \%$ more likely to watch too much TV; and those with low economic level were $139 \%$ more likely to have sedentary behavior in relation to the total screen time. Girls with skin color different from white were $66 \%$ more likely to watch too much TV. Those aged 17-19 years were $66 \%$ and $44 \%$ less likely to exceed recommendations for VG use time and total screen time, respectively.

The prevalence of excessive TV time in this survey is higher than that presented in the "Youth Risk Behavior Surveillance" report carried out in the United States ${ }^{25}$, and a survey conducted in 37 countries $^{26}$. However, both studies used cutoff points different than those used in the present study ( $\geq 3$ hours and $>3$ hours, respectively). Sur- 
Table 3. continuation

\begin{tabular}{|c|c|c|c|c|c|c|}
\hline \multirow{2}{*}{ Variable } & \multicolumn{3}{|c|}{ Crude } & \multicolumn{3}{|c|}{ Adjusted } \\
\hline & OR & $95 \% \mathrm{CI}$ & $\mathrm{p}$ & OR & 95\%CI & $\mathbf{P}$ \\
\hline \multicolumn{7}{|l|}{ Videogame } \\
\hline \multicolumn{7}{|l|}{ Age } \\
\hline $14-16$ years & 1 & & & 1 & & \\
\hline $17-19$ years & 0.82 & $0.54-1.24$ & 0.18 & 0.79 & $0.48-1.30$ & 0.18 \\
\hline \multicolumn{7}{|l|}{ Skin color } \\
\hline White & 1 & & & 1 & & \\
\hline Others ${ }^{\star}$ & 1.25 & $0.56-2.78$ & 0.34 & 1.17 & $0.33-4.13$ & 0.63 \\
\hline \multicolumn{7}{|l|}{ Maternal schooling } \\
\hline$<8$ years & 1 & & & 1 & & \\
\hline$\geq 8$ years & 1.33 & $0.81-2.18$ & 0.12 & 1.42 & $0.90-2.24$ & 0.07 \\
\hline \multicolumn{7}{|l|}{ Economic level } \\
\hline High & 1 & & & 1 & & \\
\hline Low & 1.13 & $0.79-1.63$ & 0.25 & 1.23 & $0.83-1.83$ & 0.15 \\
\hline \multicolumn{7}{|l|}{ Physcial Activity } \\
\hline Active & 1 & & & 1 & & \\
\hline Insufficiently active & 1.45 & $0.93-2.25$ & 0.06 & 1.45 & $0.98-2.04$ & 0.05 \\
\hline \multicolumn{7}{|l|}{ Screen } \\
\hline \multicolumn{7}{|l|}{ Age } \\
\hline $14-16$ years & 1 & & & 1 & & \\
\hline $17-19$ years & 0.97 & $0.09-9.50$ & 0.96 & 0.86 & $0.05-12.72$ & 0.84 \\
\hline \multicolumn{7}{|l|}{ Skin color } \\
\hline White & 1 & & & 1 & & \\
\hline Others ${ }^{\star}$ & 1.10 & $0.23-5.15$ & 0.86 & 0.94 & $0.37-2.34$ & 0.80 \\
\hline \multicolumn{7}{|l|}{ Maternal schooling } \\
\hline$<8$ years & 1 & & & 1 & & \\
\hline$\geq 8$ years & 1.29 & $0.41-4.06$ & 0.43 & 1.87 & $0.53-6.51$ & 0.16 \\
\hline \multicolumn{7}{|l|}{ Economic level } \\
\hline High & 1 & & & 1 & & \\
\hline Low & 2.20 & $1.84-2.63$ & $<0.01$ & 2.39 & $2.04-2.80$ & $<0.01$ \\
\hline \multicolumn{7}{|l|}{ Physcial Activity } \\
\hline Active & 1 & & & 1 & & \\
\hline Insufficiently active & 2.02 & $0.94-4.35$ & 0.05 & 1.71 & $0.51-5.73$ & 0.19 \\
\hline
\end{tabular}

The analysis of behaviors was adjusted by the level of physical activity. OR - Odds ratio; CI-confidence interval; * skin color: black, yellow, brown, indigenous; Screen - TV + computer + videogame.

veys conducted in Brazil $^{8,13}$ and Colombia ${ }^{27}$ using a two-hour cutoff point and found a prevalence of excessive TV use time similar to the present study.

Most studies use PC and VG use variables together $^{6,12,27}$, although different factors are associated with each of the behaviors ${ }^{6,14}$. In the USA, research that used time less than three hours of PC use as cutoff point ${ }^{25}$ found prevalence $(32.5 \%)$ lower than that found in this study.

The prevalence of excess total screen time in this study was greater than that in studies conducted in Colombia $(60.4 \%)^{27}$ and Brazil $(38.5 \%)^{10}$; however, these studies also differ with respect to the cutoff point used ( $>3$ hours $\geq 4$ hours). In a study conducted in northeastern
Brazil using cutoff point less than two hours, the results were similar to this study $(79.8 \%)^{28}$.

Different studies around the world have shown that exposure to screen time is significantly different between boys and girls ${ }^{7-9,11-13}$. The use of VG and PC was higher among boys in studies conducted in the United States ${ }^{11}$ and South Korea $^{12}$. The use of TV was higher among girls in South Korea ${ }^{12}$ and Brazil ${ }^{13}$. One of the possible factors that VG time was shorter in girlss may be associated with the fact that most games are developed to minimize the significant social interaction valued more by girls than by boys, moreover, the violent content of video games hinders the interest of girls for $\mathrm{VGs}^{29}$. 


\begin{tabular}{|c|c|c|c|c|c|c|c|}
\hline \multicolumn{8}{|c|}{$\begin{array}{l}\text { Table } 4 \text {. Odds Ratio and } 9 \\
\text { independent variables in }\end{array}$} \\
\hline & \multirow{2}{*}{ Variable } & \multicolumn{3}{|c|}{ Crude } & \multicolumn{3}{|c|}{ Adjusted } \\
\hline & & OR & 95\%CI & p & OR & $95 \% \mathrm{CI}$ & $\mathrm{p}$ \\
\hline & \multicolumn{7}{|l|}{ Television } \\
\hline & \multicolumn{7}{|l|}{ Age } \\
\hline & $14-16$ years & 1 & & & 1 & & \\
\hline & $17-19$ years & 0.78 & $0.47-1.32$ & 0.18 & 0.79 & $0.55-1.11$ & 0.10 \\
\hline & \multicolumn{7}{|l|}{ Skin color } \\
\hline & White & 1 & & & 1 & & \\
\hline & Others ${ }^{\star}$ & 1.50 & $1.18-1.90$ & 0.01 & 1.66 & $1.35-2.04$ & $<0.01$ \\
\hline & \multicolumn{7}{|l|}{ Maternal schooling } \\
\hline & $<8$ years & 1 & & & 1 & & \\
\hline & $\geq 8$ years & 0.88 & $0.57-1.36$ & 0.34 & 0.75 & $0.42-1.24$ & 0.13 \\
\hline & \multicolumn{7}{|l|}{ Economic level } \\
\hline & High & 1 & & & 1 & & \\
\hline & Low & 0.96 & $0.61-1.51$ & 0.78 & 0.88 & $0.50-1.55$ & 0.44 \\
\hline & \multicolumn{7}{|l|}{ Physcial Activity } \\
\hline & Active & 1 & & & 1 & & \\
\hline & Insufficiently active & 1.07 & $0.59-1.92$ & 0.65 & 1.11 & $0.31-3.89$ & 0.74 \\
\hline & \multicolumn{7}{|l|}{ Computer } \\
\hline & \multicolumn{7}{|l|}{ Age } \\
\hline & $14-16$ years & 1 & & & 1 & & \\
\hline & $17-19$ years & 0.80 & $0.56-1.14$ & 0.12 & 0.85 & $0.44-1.60$ & 0.38 \\
\hline & \multicolumn{7}{|l|}{ Skin color } \\
\hline & White & 1 & & & 1 & & \\
\hline & Others ${ }^{\star}$ & 0.85 & $0.42-1.71$ & 0.42 & 0.88 & $0.41-1.89$ & 0.55 \\
\hline & \multicolumn{7}{|l|}{ Maternal schooling } \\
\hline & $<8$ years & 1 & & & 1 & & \\
\hline & $\geq 8$ years & 1.35 & $0.71-2.55$ & 0.17 & 1.45 & $0.91-2.33$ & 0.07 \\
\hline & \multicolumn{7}{|l|}{ Economic level } \\
\hline & High & 1 & & & 1 & & \\
\hline & Low & 0.94 & $0.82-1.07$ & 0.18 & 1.01 & $0.72-1.43$ & 0.84 \\
\hline & \multicolumn{7}{|l|}{ Physcial Activity } \\
\hline & Active & 1 & & & 1 & & \\
\hline & Insufficiently active & 1.06 & $0.41-2.72$ & 0.80 & 1.22 & $0.43-3.46$ & 0.48 \\
\hline
\end{tabular}

Association was found between TV use and maternal education. Other studies conducted in Europe ${ }^{6}$ and in the USA ${ }^{11}$ also found similar results, in which adolescents whose mothers had lower schooling were more likely to have risk sedentary behavior due to excess TV time. Several Mechanisms are proposed to explain this event, among them, that the absence of the mother could favor the increased TV use by children. Another thought is that less educated mothers have less knowledge about the excess of the screen exposure harms the health of adolescents, who also favors to increase the time of television use in this age group ${ }^{6}$.
Adolescents of low economic level showed longer screen time in a study developed in $\mathrm{EUA}^{28}$ and Europe ${ }^{6}$. This study is also consistent with review developed by Pate et al. ${ }^{7}$, who reported longer screen time for adolescents of lower economic class. This fact can be explained by environmental constraints of individuals of low economic level such as access to areas of practice of physical activity and safe environments near their homes, which increases the time sitting at home in front of the screen ${ }^{6,728}$.

In this study, boys and girls of color black/ brown /yellow/indigenous were more likely to exceed the time indicated for sedentary screen 
Table 4. continuation

\begin{tabular}{|c|c|c|c|c|c|c|}
\hline \multirow{2}{*}{ Variable } & \multicolumn{3}{|c|}{ Crude } & \multicolumn{3}{|c|}{ Adjusted } \\
\hline & OR & 95\%CI & p & OR & 95\%CI & $\mathbf{p}$ \\
\hline \multicolumn{7}{|l|}{ Videogame } \\
\hline \multicolumn{7}{|l|}{ Age } \\
\hline $14-16$ years & 1 & & & 1 & & \\
\hline $17-19$ years & 0.60 & $0.50-0.72$ & $<0.01$ & 0.47 & $0.41-0.55$ & $<0.01$ \\
\hline \multicolumn{7}{|l|}{ Skin color } \\
\hline White & 1 & & & 1 & & \\
\hline Others* & 1.55 & $0.97-2.36$ & 0.05 & 1.64 & $0.83-3.24$ & 0.08 \\
\hline \multicolumn{7}{|l|}{ Maternal schooling } \\
\hline$<8$ years & 1 & & & 1 & & \\
\hline$\geq 8$ years & 1.15 & $0.33-3.95$ & 0.67 & 1.15 & $0.33-3.91$ & 0.67 \\
\hline \multicolumn{7}{|l|}{ Economic level } \\
\hline High & 1 & & & 1 & & \\
\hline Low & 0.90 & $0.47-1.69$ & 0.55 & 1.16 & $0.42-3.24$ & 0.58 \\
\hline \multicolumn{7}{|l|}{ Physcial Activity } \\
\hline Active & 1 & & & 1 & & \\
\hline Insufficiently active & 0.86 & $0.07-9.89$ & 0.82 & 0.93 & $0.09-9.28$ & 0.90 \\
\hline \multicolumn{7}{|l|}{ Screen } \\
\hline \multicolumn{7}{|l|}{ Age } \\
\hline $14-16$ years & 1 & & & 1 & & \\
\hline $17-19$ years & 0.60 & $0.36-0.98$ & 0.04 & 0.56 & $0.39-0.81$ & 0.02 \\
\hline \multicolumn{7}{|l|}{ Skin color } \\
\hline White & 1 & & & 1 & & \\
\hline Others $^{\star}$ & 0.73 & $0.23-2.30$ & 0.37 & 0.79 & $0.17-3.55$ & 0.58 \\
\hline \multicolumn{7}{|l|}{ Maternal schooling } \\
\hline$<8$ years & 1 & & & 1 & & \\
\hline$\geq 8$ years & 1.11 & $0.93-1.32$ & 0.12 & 1.07 & $0.72-1.58$ & 0.52 \\
\hline \multicolumn{7}{|l|}{ Economic level } \\
\hline High & 1 & & & 1 & & \\
\hline Low & 0.91 & $0.33-2.51$ & 0.75 & 0.94 & $0.40-2.21$ & 0.81 \\
\hline \multicolumn{7}{|l|}{ Physcial Activity } \\
\hline Active & 1 & & & 1 & & \\
\hline Insufficiently active & 1.22 & $0.47-3.11$ & 0.45 & 1.19 & $0.42-3.36$ & 0.53 \\
\hline
\end{tabular}

The analysis of behaviors was adjusted by the level of physical activity. OR - Odds ratio; CI-confidence interval; "skin color: black, yellow, brown, indigenous; Screen - TV + computer + videogame.

time behavior-based. Pate et al. ${ }^{7}$ systematic review of research on sedentary behavior in adolescents and associated factors of the 76 articles included, 12 described the association between sedentary behavior with skin color, of these, 10 have concluded that color of skin does not teenagers white showed higher exposure to sedentary behavior. As well as other health inequalities in Brazil, non-white skin color individuals have more difficult access to essential health and education services ${ }^{30}$, which can contribute to more idleness time, increasing sedentary behavior based on TV time.

Older girls were less likely to have sedentary behavior in relation to total screen time and VG use time than younger girls. Similar results were found in studies carried out in South Korea ${ }^{12}$ and Brazil $^{8,13}$. The pattern of lower use of screen by older girls is consistent with what happens to adolescents at this stage of life. Older girls spend less time with features that diminish social interaction, for example, TV and VG, and increase the 
use of time in other electronic equipment that facilitate interpersonal relationships, such as the use of tablets and smartphones ${ }^{31}$.

This study found that sedentary behavior based on screen time was independent of physical activity levels. No objective of this research exploring this discussion, however, this survey reports that people may be sedentary and to have adequate levels of physical activity (and vice versa). Thus, these behaviors can coexist ${ }^{1-6}$.

The cross-sectional design of this study is a limitation, which does not allow establishing causal relationships on sedentary behavior. As strengths of this study, the independent association of the different types of sedentary behavior based on screen time can be highlighted, allowing greater understanding of the subject from different forms of sedentary behavior. Another strong point of this study was the use of a random cluster sampling with instruments valid and reproducible. Thus, the external validity of the research was guaranteed and the results can be generalized to other locations with similar socioeconomic conditions.

It is concluded that boys and girls spend different times in screen-based entertainments, and there is a high prevalence with respect to the total screen time followed by PC use, TV and VG. Boys had higher prevalence of excessive VG use. Additionally, boys of skin color different from white and those whose mothers studied less than eight years were more likely to watch TV above recommended levels. Boys of low socioeconomic status were more likely to exceed total screen time. Girls of white skin color were less likely to watch TV above recommendations and older girls were less likely to have sedentary behavior based on total screen and VG time.

The high prevalence of sedentary behavior based on screen time in the present study suggests that new public policies are adopted, such as: (i) provision of leisure activities at the place where adolescents live; (ii) offer and control of the participation of adolescents in sports activities at school. 


\section{Collaborations}

GR Sousa participated in the assessment of adolescents, as well as their design analysis and interpretation of data and writing of the article. DAS Silva participated in the analysis and interpretation of data, article writing and critical review

\section{Acknowledgments}

The authors would like to thank the Federal University of Santa Catarina, the National Council for Scientific Development (CNPq) and the Coordination of Improvement of Higher Education Personnel (CAPES), subsidies for research.

\section{References}

1. Owen N, Bauman A, Brown W. Too much sitting: a novel and important predictor of chronic disease risk? Br J Sports Med 2009; 43(2):81-83.

2. Tremblay MS, LeBlanc AG, Kho ME, Saunders TJ, Larouche R, Colley RC, Goldfield G, Connor Gorber S. Systematic review of sedentary behaviour and health indicators in school-aged children and youth. Int J Behav Nutr Phys Act 2011; 8(1):98.

3. Iannotti RJ, Wang J. Trends in Physical Activity, Sedentary Behavior, Diet, and BMI Among US Adolescents, 2001-2009. Pediatrics 2013; 132(4):606-614.

4. Nelson MC, Neumark-Stzainer D, Hannan PJ, Sirard JR, Story M. Longitudinal and Secular Trends in Physical Activity and Sedentary Behavior During Adolescence. Pediatrics 2006; 118(6):e1627-1634.

5. Thorp AA, Owen N, Neuhaus M, Dunstan DW. Sedentary Behaviors and Subsequent Health Outcomes in Adults: A Systematic Review of Longitudinal Studies, 1996-2011. Am J Prev Med 2011; 41(2):207-215.

6. Rey-López JP, Tomas C, Vicente-Rodriguez G, Gracia-Marco L, Jiménez-Pavón D, Pérez-Llamas F, Redondo C, Bourdeaudhuij ID, Sjöström M, Marcos A, Chillón P, Moreno LA; AVENA Study Group Sedentary behaviours and socio-economic status in Spanish adolescents: the AVENA study. Eur J Public Health 2011; 21(2):151-157.

7. Pate RR, Mitchell JA, Byun W, Dowda M. Sedentary behaviour in youth. Br J Sports Med. 2011; 45(11):906913.

8. Silva KS, Nahas MV, Hoefelmann LP, Lopes AS, Oliveira ES. Associations between physical activity, body mass index, and sedentary behaviors in adolescents. Rev bras epidemiol 2008; 11(1):159-168.

9. Tenório MCM, Barros MVG, Tassitano RM, Bezerra J, Tenório JM, Hallal PC. Physical activity and sedentary behavior among adolescent high school students. Rev bras epidemiol. 2010; 13(1):105-117.

10. Silva KS, Nahas MV, Peres KG, Lopes AS. Factors associated with physical activity, sedentary behavior, and participation in physical education among high school students in Santa Catarina State, Brazil. Cad Saude Publica 2009; 25(10):2187-2200.

11. Babey SH, Hastert TA, Wolstein J. Adolescent Sedentary Behaviors: Correlates Differ for Television Viewing and Computer Use. J Adolesc Health 2013; 52(1):70-76.

12. Byun W, Dowda M, Pate RR. Associations Between Screen-Based Sedentary Behavior and Cardiovascular Disease Risk Factors in Korean Youth. J Korean Med Sci 2012; 27(4):388-394.

13. Silva DAS, Tremblay MS, Gonçalves ECA, Silva RJS. Television Time among Brazilian Adolescents: Correlated Factors are Different between Boys and Girls. The Scientific World Journal 2014; 2014:794539.

14. Marsh S, Ni Mhurchu C, Jiang Y, Maddison R. Comparative effects of TV watching, recreational computer use, and sedentary video game play on spontaneous energy intake in male children. A randomised crossover trial. Appetite 2014; 77:13-18.

15. Brasil. Programa das Nações Unidas para o Desenvolvimento. Atlas do Desenvolvimento Humano no Brasil. Brasília: Ipea; 2013

16. Luiz RR, Magnanini MMF. A lógica da determinaçäo do tamanho da amostra em investigaçöes epidemiológicas. Cad Saude Publica 2000; 8(2):9-28. 
17. Kuhnen M, Boing AF, Oliveira MC, Longo GZ, Njaine K. Smoking and associated factors in Brazilian adults: a population-based study. Rev bras epidemiol 2009; 12(4):615-626.

18. Martins MO, Cavalcante VLF, Holanda GS,Oliveira CG, Maia FES, Meneses Junior JR, Farias Júnior JC. Associação entre comportamento sedentário e fatores psicossociais e ambientais em adolescentes da região nordeste do Brasil. Rev Bras Ativ Fís Saúde 2012; 17(2):143-150.

19. American Academy of Pediatrics (AAP). Committee on Public Education. American Academy of Pediatrics: Children, adolescents, and television. Pediatrics 2001; 107(2):423-436.

20. Instituto Brasileiro de Geografia e Estatística (IBGE). Metodologia do censo demográfico 2010. Rio de Janeiro: IBGE; 2013.

21. Associação Brasileira de Empresas e Pesquisas (ABEP). Critério de Classificação Econômica Brasil, Brasil. [ acessado 2014 Jul 01] . Disponível em: www.abep.org.

22. Krieger N, Williams DR, Moss NE. Measuring social class in US public health research: concepts, methodologies, and guidelines. Annu Rev Public Health 1997; 18:341-378.

23. Guedes DP, Lopes CC. Validação da versão brasileira do Youth Risk Behavior Survey 2007. Rev Saude Publica 2010; 44(5):840-850

24. World Health Organization (WHO). Global recommendations on physical activity for health. Geneva: WHO; 2010.

25. Kann L, Kinchen S, Shanklin SL, Flint KH, Kawkins J, Harris WA, Lowry R, Olsen EO, McManus T, Chyen D, Whittle L, Taylor E, Demissie Z, Brener N, Thornton J, Moore J, Zaza S; Centers for Disease Control and Prevention (CDC). Youth risk behavior surveillance-United States, 2013. MMWR Surveill Summ 2014; 13(63):1168.
26. Braithwaite I, Stewart AW, Hancox RJ, Beasley R, Murphy R, Mitchell EA; ISAAC Phase Three Study Group. The Worldwide Association between Television Viewing and Obesity in Children and Adolescents: Cross Sectional Study. PLoS ONE 2013; 8(9):e74263.

27. Arango CM, Parra DC, Gómez LF, Lema L, Lobelo F, Ekelund U. Screen time, cardiorespiratory fitness and adiposity among school-age children from Monteria, Colombia. J Sci Med Sport. 2014; 17(5):491-495.

28. Smith-Menezes A, Duarte MFS, Silva RJS. Physical inactivity, sedentary behavior and overweight: association study with socioeconomic status in youth. Rev Bras Educ Fís Esporte 2012; 26(3):411-418.

29. Hartmann T, Klimmt C. Gender and Computer Games: Exploring Females' Dislikes. J Comput Mediat Commun 2006; 11(4):910-931.

30. Heringer R. Racial inequalities in Brazil: a synthesis of social indicators and challenges for public policies. $\mathrm{Cad}$ Saude Publica 2002; 18(Supl.):S57-S65

31. Kiatrungrit K, Hongsanguansri S. Cross-sectional study of use of electronic media by secondary school students in Bangkok, Thailand. Shanghai Arch Psychiatry 2014; 26(4):216-226.

Artigo apresentado em 02/07/2015

Aprovado em 19/04/2016

Versão final apresentada em 21/04/2016 